\title{
NASADA KOMINOWA SPOSOBEM INTENSYFIKACJI WYDAJNOŚCI WENTYLACJI GRAWITACYJNEJ W BUDYNKACH MIESZKALNYCH
}

\author{
Romana Antczak-Jarząbska, Maciej Niedostatkiewicz ${ }^{\bowtie}$ \\ Wydział Inżynierii Lądowej i Środowiska, Politechnika Gdańska, Gdańsk
}

\begin{abstract}
STRESZCZENIE
W Polsce wentylacja grawitacyjna jest najbardziej popularną metodą przewietrzania pomieszczeń, w tym lokali w budynkach mieszkalnych. Ten rodzaj wentylacji działa pod wpływem sił natury w wyniku różnicy ciśnień między powietrzem zewnętrznym a panującym wewnątrz obiektu, w następstwie czego wentylacje grawitacyjną trudno jest kontrolować oraz przewidywać poprawność jej funkcjonowania. Wentylacja grawitacyjna działa najlepiej zimą, gdy jest duża różnica temperatury oraz w wietrzne dni, gdy prędkość wiatru przekracza wartość $3 \mathrm{~m} \cdot \mathrm{s}^{-1}$. Najgorszy pod względem wydajności wentylacji grawitacyjnej jest okres przejściowy wiosenno-jesienny. W celu poprawy skuteczności pracy wydajności wentylacji stosuje się między innymi nasady kominowe, które mają za zadanie poprawić efekt kominowy określany w języku potocznym jako ciąg kominowy. Wydajność wentylacji określa zapotrzebowanie na powietrze wentylacyjne w pomieszczeniach. Wydajność wentylacji naturalnej $(A C H)$ jest wyznaczana na podstawie zależności, w której niezbędne jest oszacowanie ilości powietrza wychodzącego z układu wentylacyjnego w stosunku do kubatury pomieszczenia wentylowanego. W artykule przedstawiono wpływ nasady kominowej na wydajność wentylacji grawitacyjnej poprzez wyznaczone wartości $A C H$. W pracy wykorzystano wyniki z badań poligonowych przeprowadzonych $\mathrm{w}$ istniejącym budynku.
\end{abstract}

Słowa kluczowe: nasada kominowa, wentylacja grawitacyjna, $A C H$

\section{WSTĘP}

Tradycja budowlana i realia ekonomiczne w Polsce od lat preferują najtańszy z punktu widzenia inwestycyjnego system wentylacji, czyli wentylację grawitacyjną, której zasada działania polega wyłącznie na siłach natury. Mechanizmem sprawczym przepływu powietrza w mieszkaniach, jak również między wnętrzem budynku a otoczeniem jest różnica ciśnień wywołana różnicą temperatury powietrza oraz siłą wiatru [Etheridge i Sandberg, 1996; Mochida, Yoshino, Takeda, Kakegawa i Miyauchi, 2005; Santamouris i Wouters, 2006; Etheridge, 2011]. Wentylacja grawitacyjna, określana również mianem wentylacji naturalnej, powinna działać, gdy dostępne są wszystkie siły lub jedna z nich. Niestety dwa główne czynniki (temperatura i prędkość wiatru) powodujące naturalny przepływ powietrza są stochastyczne, więc sama wentylacja może być trudna do kontrolowania i przewidzenia, analizy i zaprojektowania [LBNL, 2007]. Inną wadą wentylacji grawitacyjnej jest ograniczenie kontroli nad rozdziałem powietrza w budynku i brak skuteczności w warunkach letnich przy minimalnym wietrze [Antczak-Jarząbska i Niedostatkiewicz, 2018]. W warunkach polskich wentylacja grawitacyjna działa najbardziej wydajnie zimą, gdy jest duża różnica tem-

$\triangle_{\text {maciej.niedostatkiewicz@pg.edu.pl }}$ 
peratury oraz w dni, gdy prędkość wiatru przekracza wartość $3 \mathrm{~m} \cdot \mathrm{s}^{-1}$ [Gładyszewska-Fiedoruk i Gajewski, 2012], a najgorzej w okresie wiosenno-jesienny [Fitzgerald i Woods, 2008]. Pomimo swoich wad wentylacja grawitacyjna nadal jest powszechnym rozwiązaniem, gdyż tylko ten system gwarantuje dostarczanie „Świeżego” powietrza do budynków mieszkalnych (zarówno jednorodzinnych, jak i wielorodzinnych). Badania Tombazisa [1999] wykazały, że wentylacja grawitacyjna stała się nowym trendem w projektowaniu budynków w społeczności architektonicznej. Wentylację naturalną stosuje się także w budynkach użyteczności publicznej, a nawet w szpitalach, w których są bardzo rozbudowane systemy klimatyzacji [Clarke, 2001]. Jakość wentylacji jest zwykle określana przez wskaźnik wydajności systemu wentylacyjnego. Wydajność oznacza szybkość wymiany powietrza $-A C H$ (ang. air change rate per hour), czyli jak szybko powietrze w przestrzeni wewnętrznej zostaje zastapione przez to pochodzace z zewnątrz. Wydajność wentylacji jest wskaźnikiem zdolności systemu wentylacji do usunięcia zanieczyszczeń, dlatego ważne są właściwe informacje o realistycznych danych klimatycznych dotyczących lokalnych warunków klimatycznych.

$\mathrm{W}$ artykule skupiono się przede wszystkim na ocenie wydajność wentylacji grawitacyjnej w budynku z nasada kominowa i bez niej. Nasady kominowe osłaniając przewód kominowy przed wiatrem, wytwarzają podciśnienie i tym samym wpływają na ruch powietrza wentylacyjnego w kanale [Nazaroff, 2008]. Analiza została wykonana na podstawie przeprowadzonych badań poligonowych. Podczas badań monitorowano wielkości fizyczne charakteryzujące wymianę powietrza $\mathrm{w}$ pomieszczeniu oraz parametry klimatu zewnętrznego. Pomiary wielkości fizycznych charakteryzujących przepływ powietrza w budynku wykonano w pomieszczeniu, w którym w kanale wentylacyjnym została umieszczona nasada kominowa. W artykule przedstawiono wpływ nasady kominowej typu obrotowego na poprawę siły ciągu w kanale. Pomiary prowadzono w okresie wiosennym. Do analizy wyników ciągu kominowego bez nasady kominowej i z nią wykorzystano przedział czasu, w którym jedynym czynnikiem wspomagającym ruch powietrza wentylacyjnego $\mathrm{w}$ pomieszczeniu był wiatr, którego pomierzona prędkość nie przekraczała wartości $3 \mathrm{~m} \cdot \mathrm{s}^{-1}$. Do obliczeń nie przyjęto kryterium temperatury, co oznacza, że wartości wytypowane do porównania miały temperaturę powietrza zewnętrznego $\left(t_{e}\right)$ powyżej $12^{\circ} \mathrm{C}$.

\section{MATERIA I METODY}

\section{Charakterystyka budynku referencyjnego}

Badany budynek zrealizowano jako dwukondygnacyjny, całkowicie podpiwniczony, w technologii tradycyjnej. Powstał w latach 50. XX wieku, a jego częściowa termomodernizacja została wykonana w 2012 roku. Termomodernizacja polegała na wymianie stolarki okiennej oraz na ociepleniu więźby dachowej. Mury zewnętrzne zostały wykonane $\mathrm{z}$ cegły pełnej o grubości $38 \mathrm{~cm}$, bez izolacji termicznej. Więźba dachowa została całkowicie przebudowana podczas termomodernizacji. Dach wykonano jako drewniany stromy, wielospadowy o konstrukcji jętkowej. Budynek jest wyposażony w system wentylacji grawitacyjnej. Budynek ma dwie kondygnacje nadziemne i jedną podziemna. Ukształtowanie pomieszczeń oraz otwory wentylacyjne pozwoliły na wyizolowanie do badań z całego obiektu jednego pomieszczenia (kuchnia) wraz z kanałem wentylacyjnym (rys. 1). Pomieszczenie wybrane do analizy stanowi samodzielną część pod względem systemu wentylacji, tzn. w tym obszarze występuje wlot i wylot powietrza wentylacyjnego (rys. 2). Wytypowane pomieszczenie zostało szczelnie oddzielone od pozostałych pomieszczeń. Ma ono następujące wymiary: wysokość 2,6 m, szerokość 3,5 m oraz długość 4,5 m. Wysokość komina od środka wysokości w świetle kratki wentylacyjnej w pomieszczeniu do środka na wylocie z kanału wentylacyjnego wynosi 5,46 m (rys. 3).

$\mathrm{W}$ pomieszczeniu testowym znajduje się okno PCV wykonane z profili jednokomorowych. Pomieszczenie ma dwoje drzwi. Każde z nich prowadził do pomieszczenia ogrzewanego. Komin jest wykonany w technologii tradycyjnej z cegły pełnej ceramicznej i jest otynkowany. Komin ma cztery kanały o wymiarach $14 \times 14 \mathrm{~cm}$. Komin jest wyprowadzony ponad połać dachową na wysokość $1,04 \mathrm{~m}$. Ściana zewnętrzna jest murowana $\mathrm{z}$ cegły pełnej ceramicznej o łącznej grubości $0,38 \mathrm{~m}$. Ściany działowe są murowane $\mathrm{z}$ cegły pełnej ceramicznej o grubości $0,12 \mathrm{~m}$. 


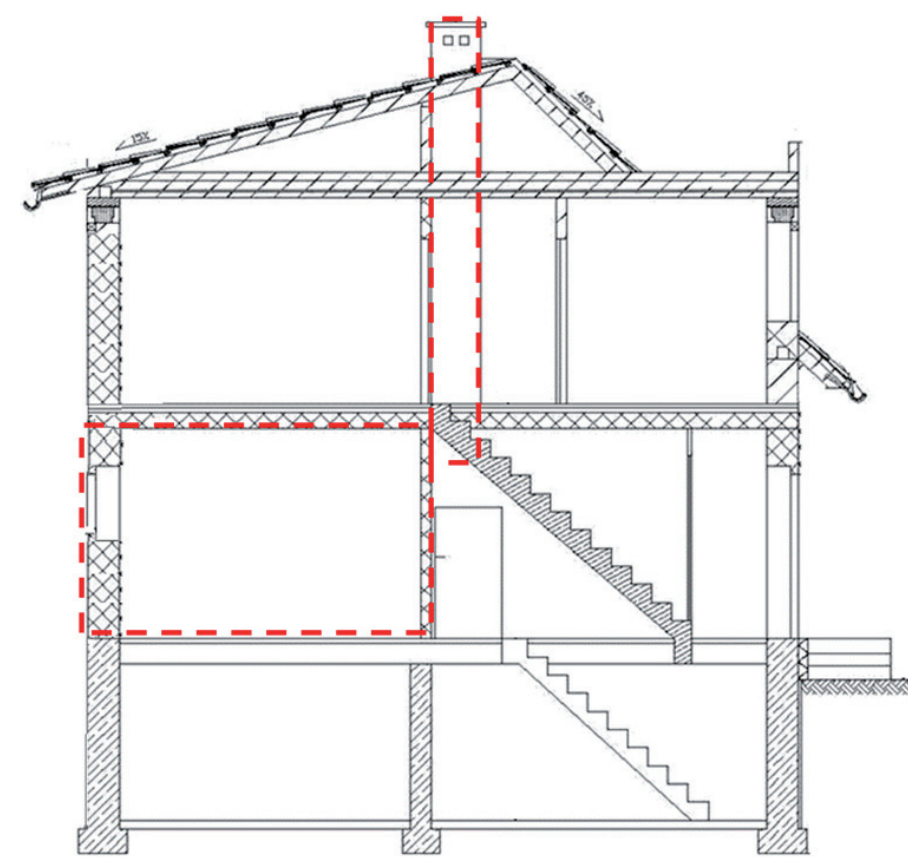

Rys. 1. Przekrój pionowy budynku testowego z oznaczonym miejscem badań poligonowych

Fig. 1. A vertical cross-section of a test building with a marked place of polygon testing

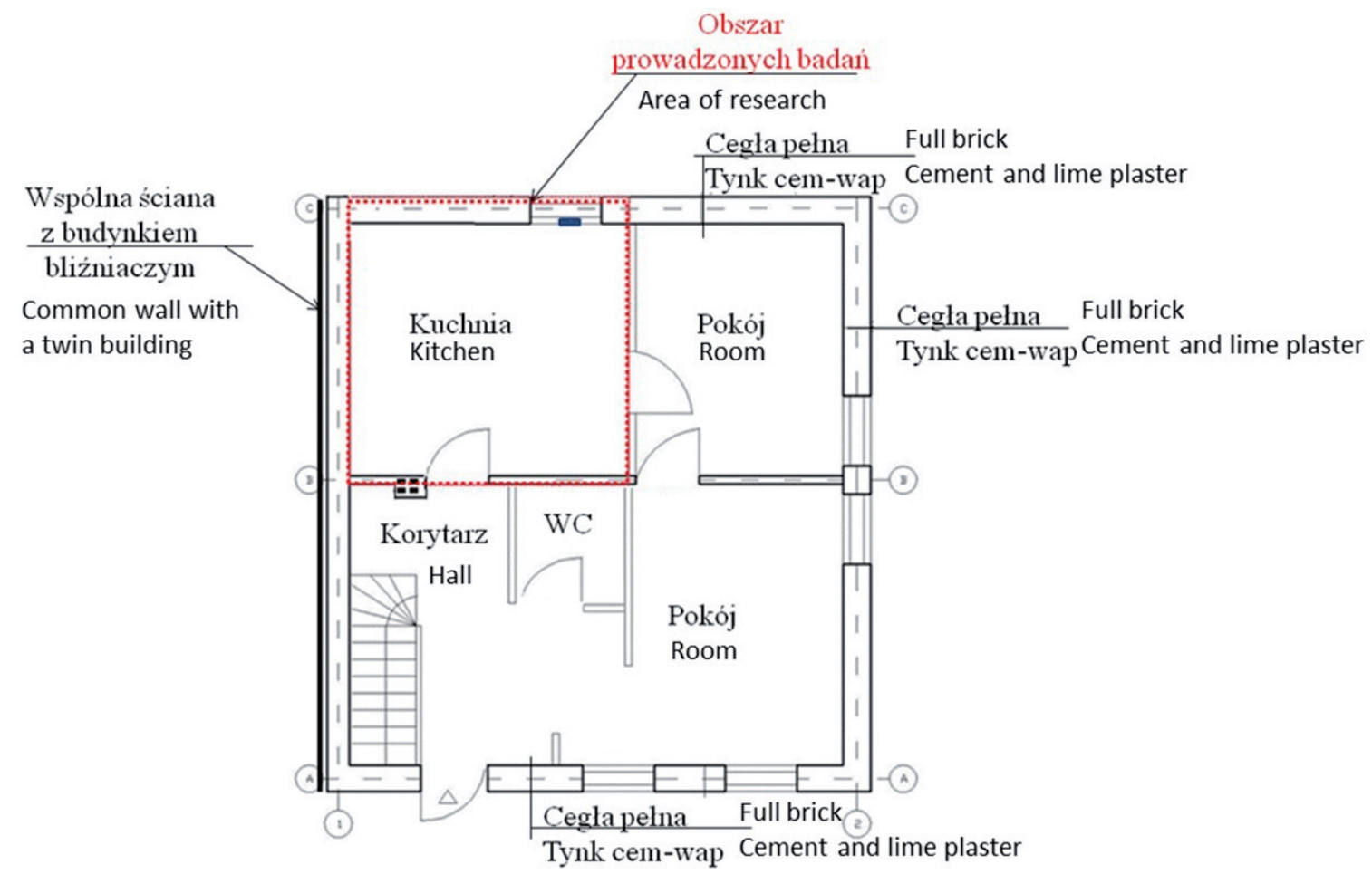

Rys. 2. Rzut budynku testowego z oznaczonym miejscem badań poligonowych

Fig. 2. Floor plan of the test building with the marked place of polygon testing 


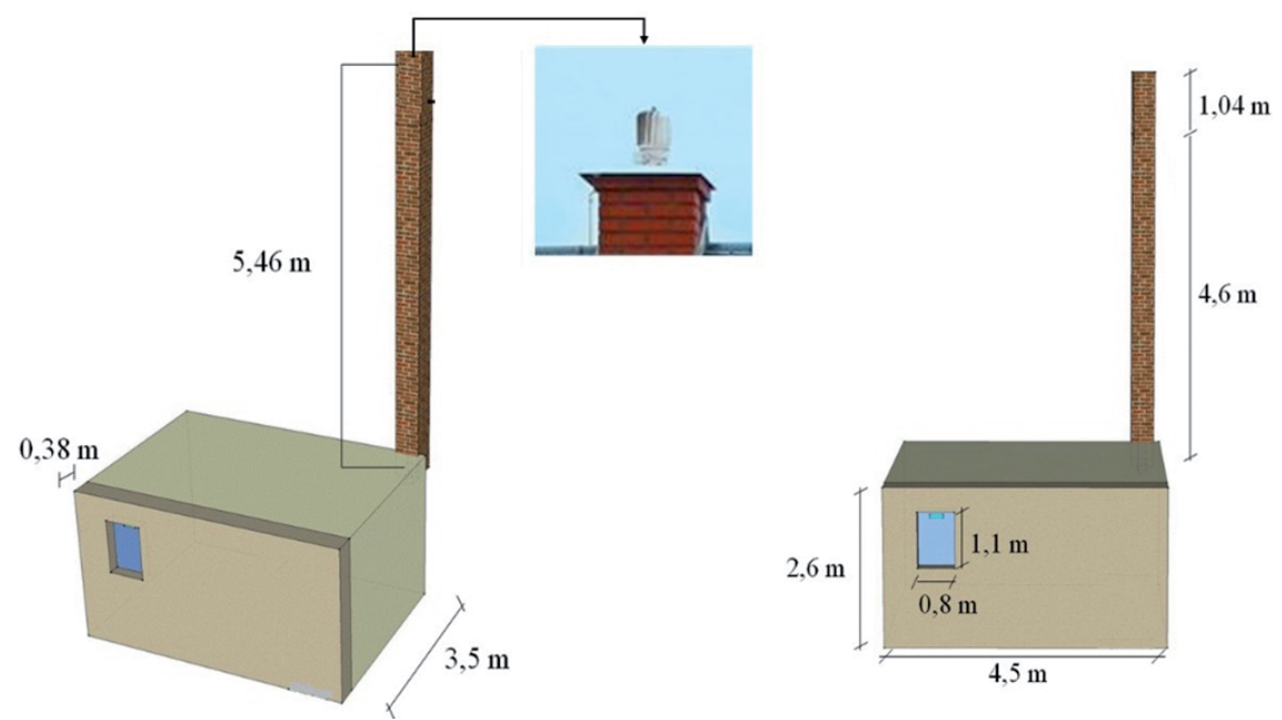

Rys. 3. Pomieszczenie testowe - wizualizacja z pokazaniem elementów system wentylacji grawitacyjnej

Fig. 3. Test - visualization room with elements of the natural ventilation system

\section{Założenia}

Jak zostało to wcześniej wspomniane, wentylacja grawitacyjna działa, jeżeli występują siły wymuszające ruch powietrza wentylacyjnego $\mathrm{w}$ pomieszczeniu, czyli odpowiednia różnica temperatury oraz odpowiednia siła wiatru. Wentylacja grawitacyjna działa prawidłowo, gdy świeże powietrze dostarczane jest otworami (nawiewnikami), następnie jest ogrzewane w pomieszczeniach i na koniec usuwane kanałami wentylacyjnymi. W tego typu wentylacji jest istotne, aby efekt kominowy (ciąg kominowy) w kanałach trzonów kominowych był zachowany.

Z badań Lau i Chena [2006] wynika, że w okresie ujemnej temperatury wydajność wentylacji naturalnej jest na zadawalającym poziomie. Na podstawie badań Gładyszewska-Fiedoruk i Gajewskiego [2012] wiadomo, że podczas występowania wiatru wentylacja naturalna, a dokładnie krotność wymian powietrza, jest nawet trzykrotnie większa niż podczas pogody bezwietrznej.

Dla potrzeby analizy w pracy przyjęto do obliczeń następujące założenia:

1. Zgodnie z normą PN-B-03430:1983 wentylacja naturalna może przestać działać prawidłowo, jeżeli temperatura powietrza zewnętrznego $\left(t_{e}\right)$ przekracza $12^{\circ} \mathrm{C}$.
2. Jako górne kryterium temperatury powietrza wewnętrznego ustalono wartość $20^{\circ} \mathrm{C}$. Powyżej tej temperatury założono, że występują ciepłe dni i można przewietrzać lub nawet chłodzić pomieszczenia.

3. Na podstawie wcześniejszych badań własnych [Antczak-Jarząbska i Niedostatkiewicz, 2016] zauważono, że gdy prędkość wiatru $\left(V_{w}\right)$ nie przekracza $3 \mathrm{~m} \cdot \mathrm{s}^{-1}$, czyli podczas tzw. ciszy wiatrowej lub tzw. słabego wiatru, nie przyczynia się do ruchu powietrza wentylacyjnego w pomieszczeniach.

\section{Opis stanowiska badawczego}

W celu poprawy wentylacji naturalnej w budynku zamontowano nasadę kominową typu obrotowego. Ocenę działania systemu wentylacji grawitacyjnej w budynku przeprowadzono na podstawie ciągłych pomiarów prędkości wiatru $\left(V_{w}\left[\mathrm{~m} \cdot \mathrm{s}^{-1}\right]\right)$, prędkości powietrza wentylacyjnego z nasadą kominową i bez niej $\left(V_{N}, B_{N}\right.$ $\left.\left[\mathrm{m} \cdot \mathrm{s}^{-1}\right]\right)$, temperatury powietrza zewnętrznego $\left(t_{z}\left[{ }^{\circ} \mathrm{C}\right]\right)$ oraz temperatury w kanale wentylacyjnym $\left(t_{k}\left[{ }^{\circ} \mathrm{C}\right]\right)$. Czujniki rejestrujące przepływ powietrza w kanale były umieszczone w kratce wentylacyjnej A2 i w kanale wentylacyjnym w odległości $0,4 \mathrm{~m}$ od wylotu A1. Pomiary wykonywano w okresie przejściowym (wiosna) z częstością próbkowania $60 \mathrm{~s}$. Do badań wykorzystano sprzęt firmy Lab-el w skład, którego wchodził: 
- wiatromierz LB-747 (składa się z dwóch czujników: czujnika prędkości i czujnika kierunku wiatru oraz przetwornika pomiarowego, dokładność pomiaru prędkości 2\%, dokładność pomiaru kierunku 3\%),

- termohigrometr LB-710R (przyrząd wykorzystuje do pomiaru dane $\mathrm{z}$ czujnika temperatury $\mathrm{z}$ termorezystorem Pt-1000 oraz z pojemnościowego czujnika wilgotności względnej, dokładność pomiaru temperatury $0,1^{\circ} \mathrm{C}$, dokładność pomiaru kierunku $2 \%$ ),

- czujnik przepływu powietrza LB-801C (w urządzeniu została wykorzystana termoanemometryczna zasada działania, dokładność pomiaru temperatury $0,1^{\circ} \mathrm{C}$, dokładność pomiaru przepływu $\left.0,05 \mathrm{~m} \cdot \mathrm{s}^{-1}\right)$,

- koncentrator zbierania danych LB-487 (elektroniczny rejestrator danych pomiarowych służy do zbierania i rejestracji danych, w szczególności temperatury, wilgotności oraz wejść binarnych i analogowych).

Podczas pomiarów monitorowano także ciśnienie powietrza zewnętrznego LB-750, jak i wewnętrznego LB-471P. Podczas prac pomiarowych nie wystapiły anomalia pogodowe, zarówno w zakresie temperatury, jak i ciśnienia oraz kierunku i prędkości wiatru. Podczas pomiarów $\mathrm{w}$ bezpośrednim sąsiedztwie budynku nieprowadzone były jakiekolwiek działania, które mogłyby mieć wpływ na zmiane warunków meteoro- logicznych. Do wykonania pomiarów zastosowano system pomiarowy z czujnikami pomiarowymi, które były skalibrowane zgodnie z wytycznymi normy ISO-IEC 17025. Schemat położenia czujników w budynku testowym przedstawia rysunek 4. Objaśnienia czujników opisano w tabeli 1.

Jako jednostkę centralną akwizycji danych zastosowano komputer podłączony do rejestratora danych pomiarowych złożonego $\mathrm{z}$ dwóch koncentratorów LB-487 i lokalnego modułu akwizycji danych. Komputer wraz $\mathrm{z}$ rejestratorem (rys. 5) umieszczono w środku pomieszczenia testowego. Pomiary wykonywano z częstotliwością próbkowania $60 \mathrm{~s}$. Pomiary były prowadzone $\mathrm{w}$ warunkach klimatu lokalnego miasta Gdańsk.

\section{Obliczenia wydajności wentylacji grawitacyjnej}

Wydajność wentylacji grawitacyjnej określa zapotrzebowanie na powietrze wentylacyjne w pomieszczeniach o stałej lub niewielkiej liczbie czynników szkodliwych i uciążliwych dla zdrowia oraz zastosowanych prostych urządzeniach wentylacyjnych. Wydajność wentylacji naturalnej jest wyznaczana na podstawie zależności, w której niezbędne jest oszacowanie ilości powietrza wychodzacego z układu wentylacyjnego do kubatury pomieszczenia wentylowanego:

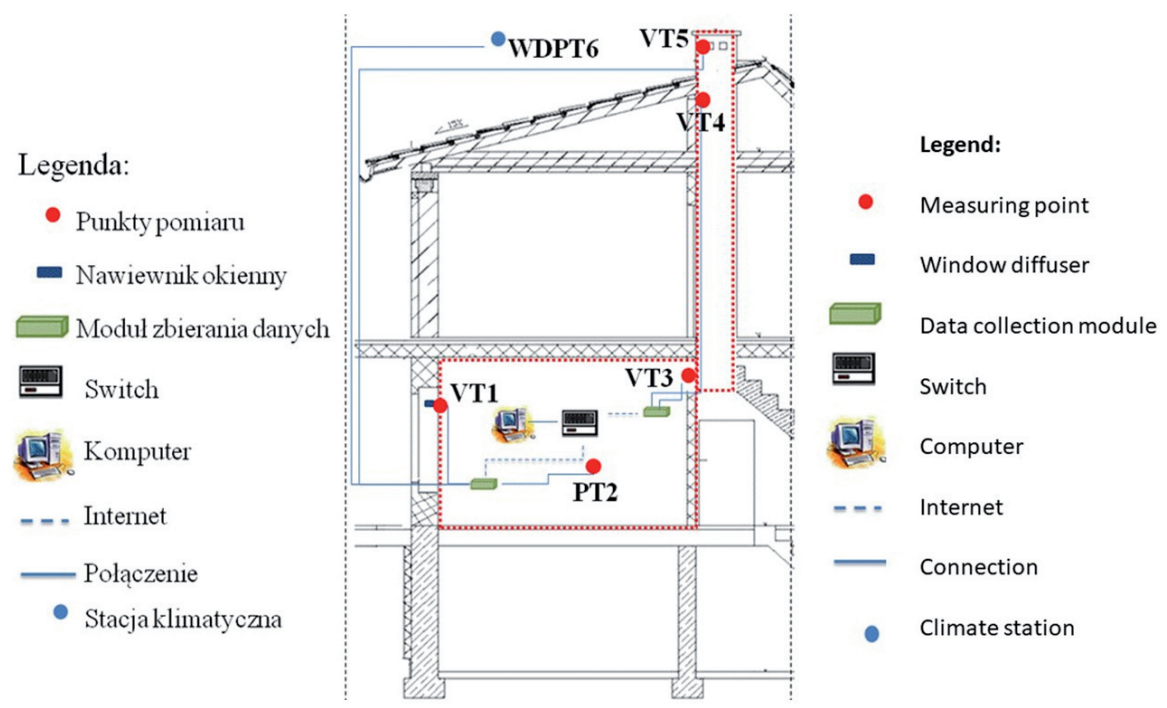

Rys. 4. Schemat położenia czujników w budynku testowym (kuchnia i kanał wentylacyjny)

Fig. 4. The position of the sensors in the test building (kitchen and ventilation duct) 
Antczak-Jarząbska, R., Niedostatkiewicz, M. (2019). Nasada kominowa sposobem intensyfikacji wydajności wentylacji grawitacyjnej w budynkach mieszkalnych. Acta Sci. Pol. Architectura 18 (1), 99-108, DOI: 10.22630/ASPA.2019.18.1.12

Tabela 1. Opis zastosowanych czujników pomiarowych

Table 1. Measuring sensors description

\begin{tabular}{|c|c|c|c|}
\hline Symbol & $\begin{array}{l}\text { Nazwa czujnika } \\
\text { Sensor name }\end{array}$ & $\begin{array}{l}\text { Mierzona wartość } \\
\text { Measured value }\end{array}$ & $\begin{array}{l}\text { Opis usytuowania czujnika } \\
\text { Description of the sensor's location }\end{array}$ \\
\hline W,D & $\begin{array}{l}\text { wiatromierz } \\
\text { wind measure }\end{array}$ & $\begin{array}{l}\text { prędkość }- \text { velocity }\left[\mathrm{m} \cdot \mathrm{s}^{-1}\right] \\
\text { kierunek - direction }\end{array}$ & $\begin{array}{l}\text { Czujnik umieszczony na południowym balkonie } \\
\text { Sensor placed on the southern balcony }\end{array}$ \\
\hline $\mathrm{P} 2,6$ & $\begin{array}{l}\text { barometr } \\
\text { barometer }\end{array}$ & ciśnienie - pressure $[\mathrm{hPa}]$ & $\begin{array}{c}\text { Czujnik umieszczony na południowym balkonie (P6) } \\
\text { oraz w pomieszczeniu testowym (P2) } \\
\text { The sensor is located on the southern balcony (P6) } \\
\text { and in the test room (P2) }\end{array}$ \\
\hline $\mathrm{T} 2$ & $\begin{array}{c}\text { termometr } \\
\text { thermometer }\end{array}$ & temperatura - temperatura $\left[{ }^{\circ} \mathrm{C}\right]$ & $\begin{array}{l}\text { Czujnik umieszczony w pomieszczeniu testowym } \\
\text { The sensor placed in the test room }\end{array}$ \\
\hline T6 & $\begin{array}{l}\text { termometr } \\
\text { thermometer }\end{array}$ & temperatura - temperatura $\left[{ }^{\circ} \mathrm{C}\right]$ & $\begin{array}{l}\text { Czujnik umieszczony na poludniowym balkonie } \\
\text { Sensor placed on the southern balcony }\end{array}$ \\
\hline \multirow{2}{*}{ VT1 } & \multirow{2}{*}{$\begin{array}{l}\text { termoanemometr } \\
\text { thermo-anemometer }\end{array}$} & prędkość - velocity $\left[\mathrm{m} \cdot \mathrm{s}^{-1}\right]$ & $\begin{array}{l}\text { Czujnik umieszczony w świetle nawiewnika } \\
\text { okiennego w pomieszczeniu testowym }\end{array}$ \\
\hline & & temperatura - temperatura $\left[{ }^{\circ} \mathrm{C}\right]$ & $\begin{array}{l}\text { Sensor placed in the light of the window ventilator } \\
\text { in the test room }\end{array}$ \\
\hline \multirow{2}{*}{ VT3 } & \multirow{2}{*}{$\begin{array}{l}\text { termoanemometr } \\
\text { thermo-anemometer }\end{array}$} & prędkość - velocity $\left[\mathrm{m} \cdot \mathrm{s}^{-1}\right]$ & $\begin{array}{c}\text { Czujnik umieszczony w świetle otworu } \\
\text { wentylacyjnego w pomieszczeniu testowym }\end{array}$ \\
\hline & & temperatura - temperatura $\left[{ }^{\circ} \mathrm{C}\right]$ & $\begin{array}{l}\text { Sensor placed in the light of the ventilation opening } \\
\text { in the test room }\end{array}$ \\
\hline \multirow{2}{*}{ VT4 } & \multirow{2}{*}{$\begin{array}{l}\text { termoanemometr } \\
\text { thermo-anemometer }\end{array}$} & prędkość - velocity $\left[\mathrm{m} \cdot \mathrm{s}^{-1}\right]$ & $\begin{array}{c}\text { Czujnik umieszczony w kanale wentylacyjnym na } \\
\text { długości } 1,5 \text { m od dolnej krawędzi otworu } \\
\text { wentylacyjnego w kominie }\end{array}$ \\
\hline & & temperatura - temperatura $\left[{ }^{\circ} \mathrm{C}\right]$ & $\begin{array}{l}\text { The sensor is placed in the ventilation duct at the } \\
\text { length of } 1.5 \mathrm{~m} \text { from the bottom edge of } \\
\text { the ventilation opening in the chimney }\end{array}$ \\
\hline VT5 & $\begin{array}{l}\text { termoanemometr } \\
\text { thermo-anemometer }\end{array}$ & prędkość - velocity $\left[\mathrm{m} \cdot \mathrm{s}^{-1}\right]$ & $\begin{array}{l}\text { Czujnik umieszczony w świetle otworu } \\
\text { wentylacyjnego w kominie } \\
\text { The sensor is placed in the light of the ventilation } \\
\text { opening in the chimney }\end{array}$ \\
\hline
\end{tabular}

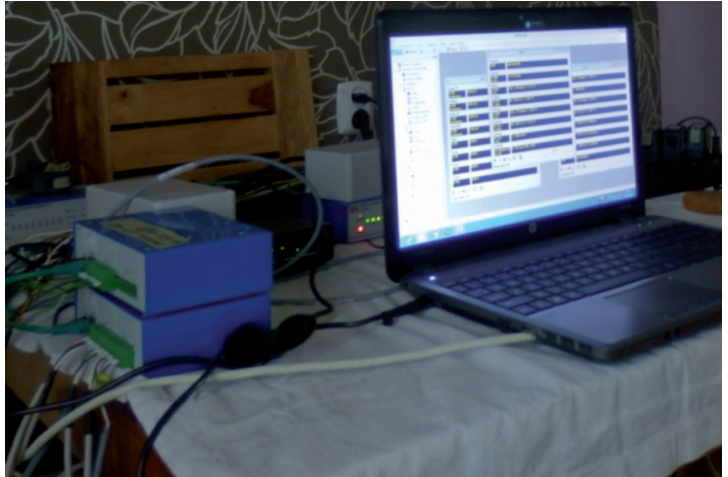

Rys. 5. Widok stanowiska pomiarowego - komputer rejestrujący dane pomiarowe wraz z koncentratorem LB-487

Fig. 5. View of the measuring stand - a computer registering measurement data with the concentrator LB-487

$$
A C H(t)=\frac{\dot{V}(t) \cdot 3600}{V_{R}}
$$

gdzie:

$A C H(t)$ - krotność wentylacji naturalnej (wydajność wentylacji) $\left[\mathrm{h}^{-1}\right]$,

$\dot{V}(t)$ - ilość powietrza wychodzącego z układu wentylacyjnego $\left[\mathrm{m}^{3} \cdot \mathrm{s}^{-1}\right]$,

$V_{R}$ - kubatury pomieszczenia wentylowanego $\left[\mathrm{m}^{3}\right]$.

Proces wymiany powietrza w czasie pomiaru przyjęto jako wartość niezależną od czasu. W związku z tym ilość powietrza wychodzącego z układu wentylacyjnego $-\dot{V}(t)$, a zatem i krotność wentylacji naturalnej - $A C H(t)$, przyjmuje się jako wartości stałe $-\dot{V}$ i $A C H$. Dla wyznaczenia krotności wentylacji natural- 
nej, która ma na celu pokazanie wydajności wentylacji, wprowadzono następujące uproszczenia:

- powietrze podczas pomiarów uważa się za dokładnie wymieszane,

- wewnątrz pomieszczenia nie występują gradienty; oznacza to, że koncentracja powietrza jest taka sama w całym układzie wentylacyjnym.

\section{WYNIKI}

Pomiar krotności wymian powietrza $(A C H)$ dla testowanego pomieszczenia wykonano dla dwóch przypadków: bez nasady kominowej i z nią. W pierwszej kolejności mierzono $A C H$ dla pomieszczenia $\mathrm{z}$ zamontowana na kominie nasadą, ponieważ badanie dotyczyło dwóch różnych przedziałów czasu, w związku z tym porównano jedynie wyniki, w których wystąpiły takie same warunki klimatu zewnętrznego.

Do analizy wyników krotności wymian powietrza $(A C H)$ wykorzystano przedział czasu, w którym jedynym czynnikiem wspomagającym ruch powietrza wentylacyjnego $\mathrm{w}$ pomieszczeniu był wiatr. Warunki klimatu zewnętrznego przyjęte do analizy: temperatura powietrza zewnętrznego powyżej $12^{\circ} \mathrm{C}$ i prędkość wiatru w granicach od $1 \mathrm{do} 3 \mathrm{~m} \cdot \mathrm{s}^{-1}$. Dla powyższych założeń sporządzono wykres krotności wymian powietrza $(A C H)$. Rysunek 6 przedstawia rozkład wartości $A C H$ przed zamontowaniem nasady kominowej. Rysunek 6 pokazuje dużą zmienność $A C H$ podczas słabego wiatru. Szybkość wymiany powietrza w doświadczeniu była bardzo zmienna, ponieważ $A C H_{\min }$ $\approx 0,08 \mathrm{~h}^{-1}$, a $A C H_{\max } \approx 1,28 \mathrm{~h}^{-1}$. Średnia zmierzona szybkość wymiany powietrza dla wentylacji grawitacyjnej przed zainstalowaniem nasady kominowej wyniosła $A C H \approx 0,75$. Według zaleceń normy PN-B-03430:1983 dopływ powietrza zewnętrznego do pomieszczeń powinien mieścić się $\mathrm{w}$ granicach od 20 do $50 \mathrm{~m}^{3} \cdot \mathrm{h}^{-1}$, przy założeniu, że strumień objętości powietrza przepływa przez całkowicie otwarty nawiewnik, przy różnicy ciśnienia 10 Pa po obu jego stronach. W przypadku wentylacji grawitacyjnej bez nasady kominowej wymiana powietrza została spełniona dla około $49 \%$ czasu pomiaru.

Rysunek 7 przedstawia $A C H$ po zamontowaniu nasady kominowej. Szybkość wymiany powietrza w doświadczeniu była bardzo zmienna, ponieważ $A C H_{\min } \approx 0,25 \mathrm{~h}^{-1}$, a $A C H_{\max } \approx 1,43 \mathrm{~h}^{-1}$. Średnia zmierzona szybkość wymiany powietrza dla wentylacji grawitacyjnej przed zainstalowaniem nasady kominowej wyniosła $A C H \approx 0,89$. Zgodnie $\mathrm{z}$ zaleceniami

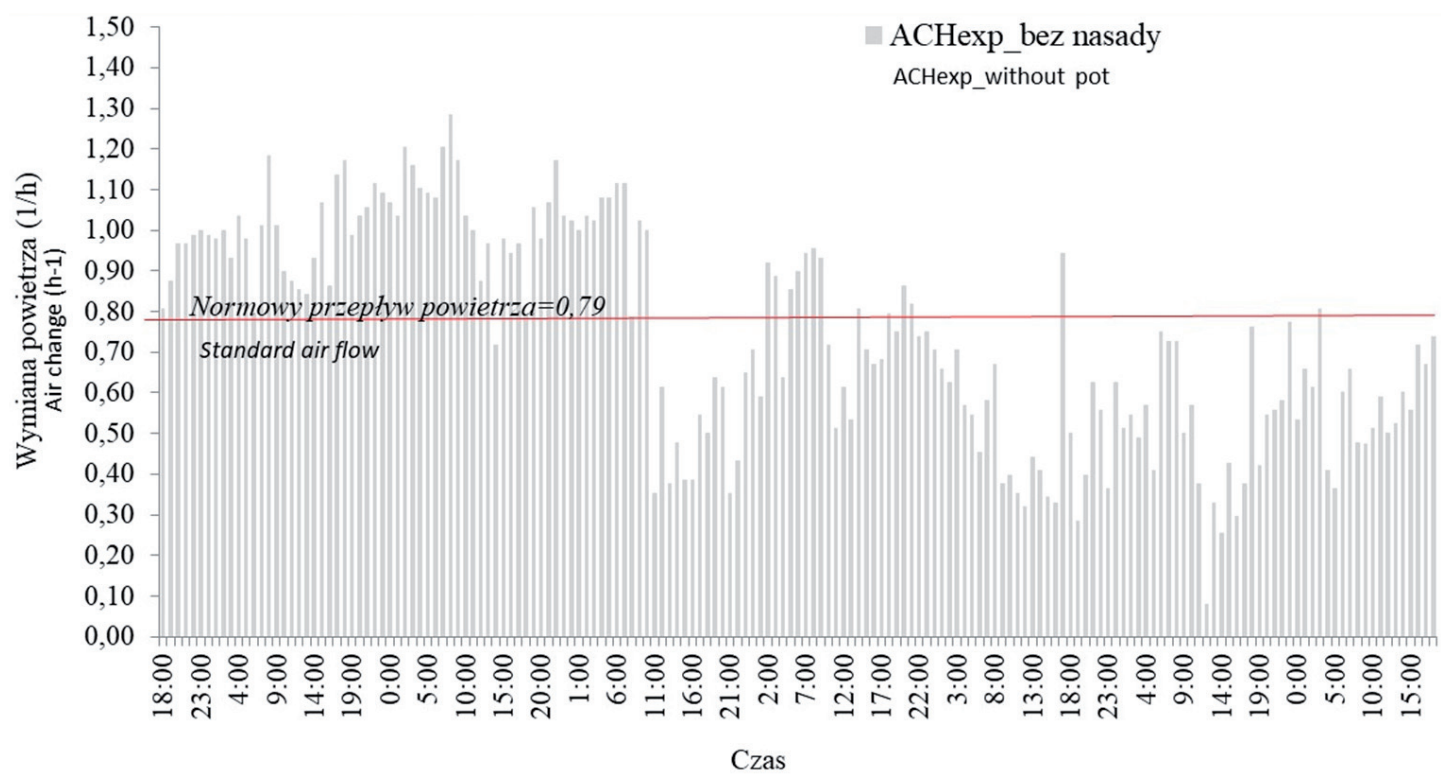

Rys. 6. Pomiar krotności wymian powietrza $(A C H)$ dla testowanego pomieszczenia bez nasady kominowej

Fig. 6. Measurement of the air exchange rate $(A C H)$ for the tested room without chimney pot 


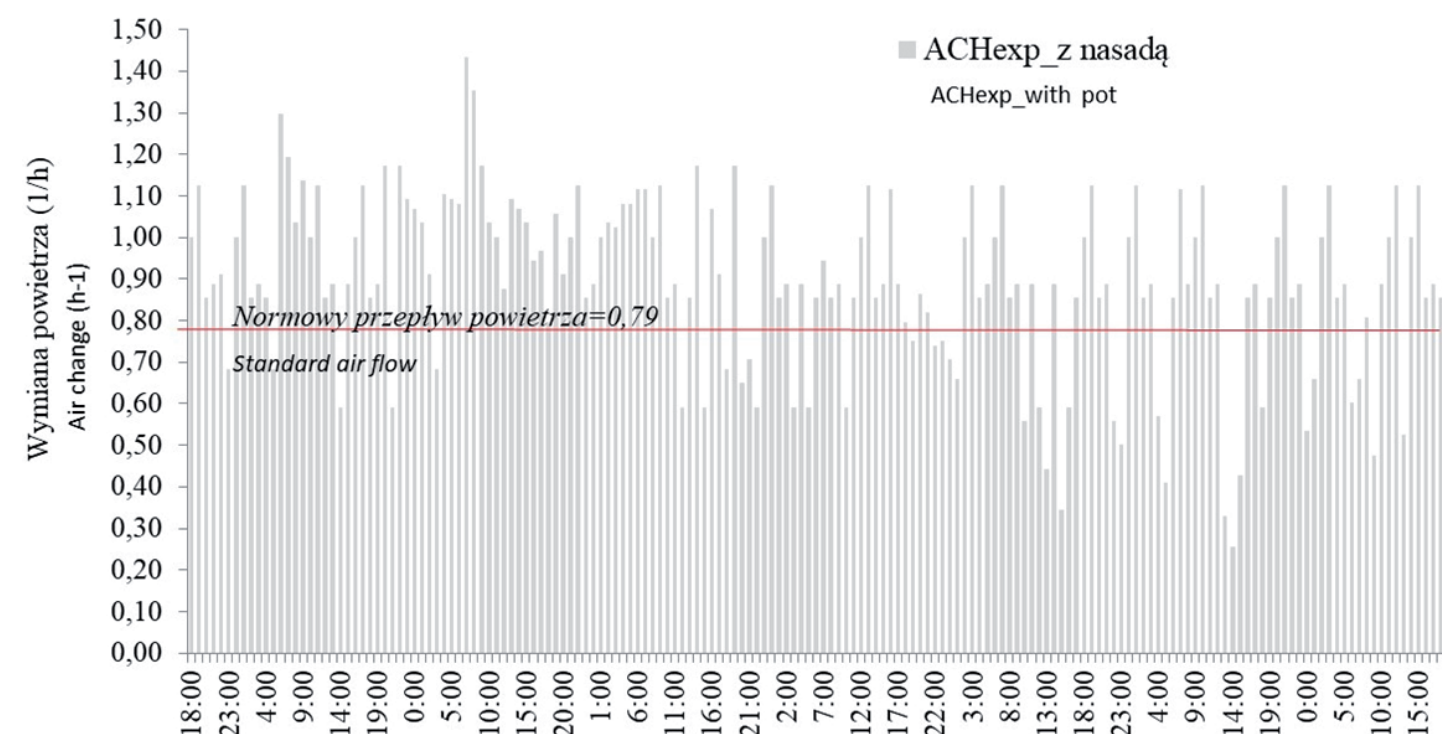

Czas

Time

Rys. 7. Pomiar krotności wymian powietrza $(A C H)$ dla testowanego pomieszczenia bez nasady kominowej

Fig. 7. Measurement of the air exchange rate $(A C H)$ for the tested room with chimney pot

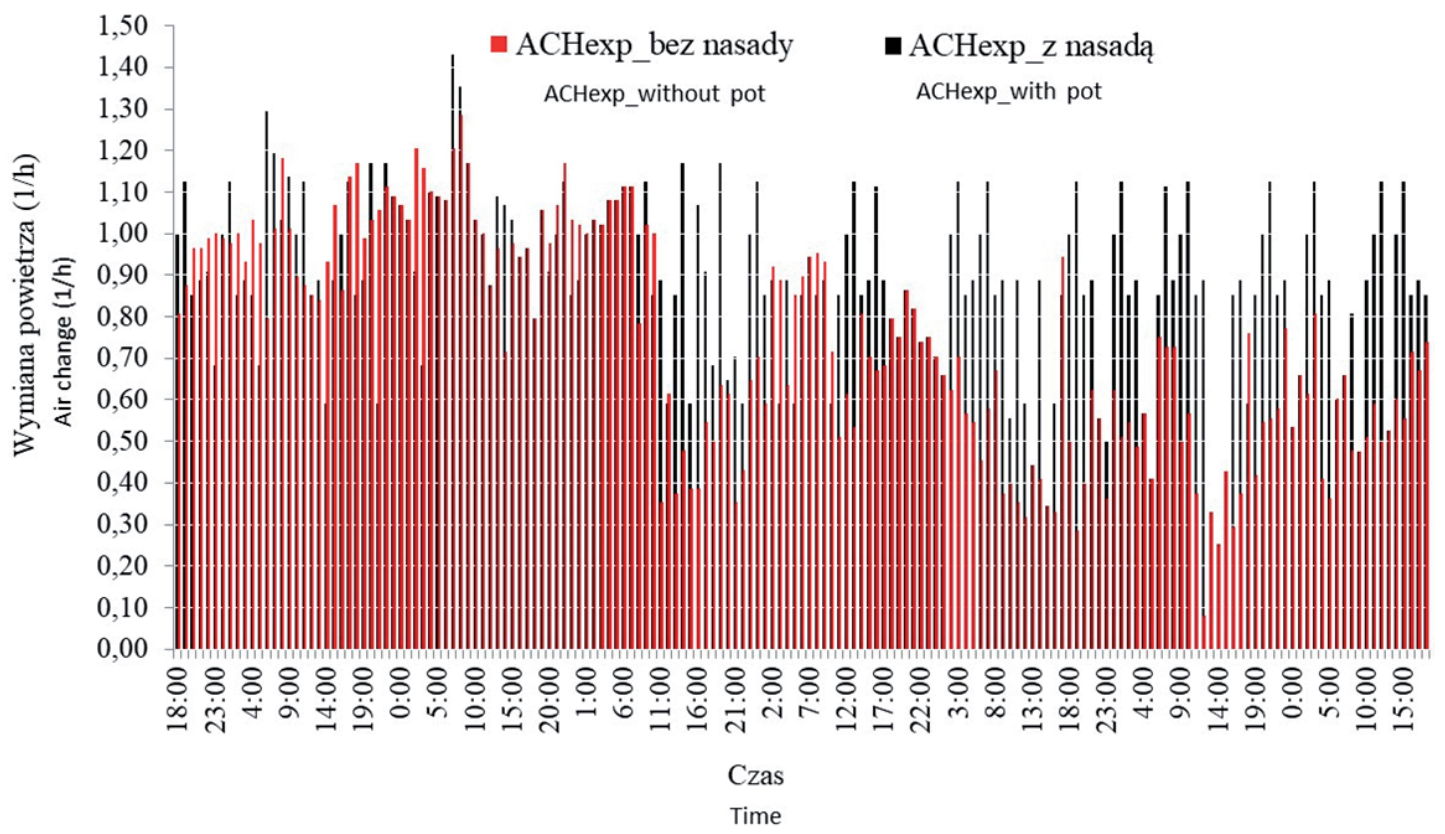

Rys. 8. Pomiar krotności wymian powietrza $(A C H)$ dla testowanego pomieszczenia - porównanie wyników

Fig. 8. Measurement of the air exchange rate $(A C H)$ for the tested room - comparison of results 
normy PN-B-03430:1983 w przypadku wentylacji grawitacyjnej z nasadą kominową wymiana powietrza została spełniona dla około $86 \%$ czasu pomiaru.

Rysunek 8 przedstawia porównanie wyników $A C H$ bez nasady kominowej (rys. 6) i z nią (rys. 7). Podobne wartości $A C H$ (bez nasady kominowej i z nią) zauważalne są przy wystąpieniu wiatru, gdy $A C H>0,9$. Zdecydowane różnice w $A C H$ występują podczas słabego wiatru, w tym czasie kanał wentylacyjny z nasadą kominową cechował się większą wymiana powietrza niż kanał wentylacyjny bez nasady kominowej.

\section{WNIOSKI}

Analiza wyników pokazała, że dla przedziału czasu, w którym skuteczność wentylacji grawitacyjnej jest najgorsza, zastosowanie nasady kominowej może zwiększyć średnią krotność wymiany powietrza o okoto $20 \%$. Przeprowadzone badania, które należy uznać za studium przypadku, wykazały, że zastosowana nasada kominowa przy niewielkiej prędkości wiatru (mniej niż $3 \mathrm{~m} \cdot \mathrm{s}^{-1}$ ) pozwoliła zmienić energie wiatru na podciśnienie w kanale, które zwiększyło wymianę powietrza wentylacyjnego $\mathrm{w}$ pomieszczeniu.

Poza istotnym zwiększeniem wymiany powietrza w pomieszczeniu ważne jest też to, że zastosowanie nasady w kanale wentylacyjnym zmniejsza prawdopodobieństwo odwrócenia się ciągu wentylacyjnego. Nie zachodzi zatem obawa, że w przypadku niekorzystnych warunków atmosferycznych nie będzie zapewniony prawidłowy kierunek przepływu powietrza.

\section{PIŚMIENNICTWO}

Antczak-Jarząbska, R. i Niedostatkiewicz, M. (2016). Badania termowizyjne ciągu wentylacyjnego. Dachy, 1 , $10-15$.

Antczak-Jarząbska, R. i Niedostatkiewicz, M. (2018). Natural ventilation performance of family building in cold climate during windy days. Diagnostyka, 19 (1), 103-116. doi: 10.29354/diag/82977
Clarke, D. (2001). A breath of fresh air. Hospital Development, 32 (11), 13-17.

Etheridge, D. (2011). Natural Ventilation of Buildings: Theory, Measurement and Design. Chichester: John Wiley $\&$ Sons.

Etheridge, D. i Sandberg, M. (1996). Building Ventilation: Theory and Measurement. Chichester: John Wiley \& Sons.

Fitzgerald, S. D. i Woods, A. W. (2008). The influence of stacks on flow patterns and stratification associated with natural ventilation. Energy and Buildings, 43, 1719-1733. doi: 10.1016/j.buildenv.2007.10.021

Gładyszewska-Fiedoruk, K., Gajewski, A. (2012). Effect of wind on stack ventilation performance. Energy and Buildings, 51, 242-247. doi: 10.1016/j.enbuild.2012.05.007

ISO-IEC 17025. Ogólne wymagania dotyczące laboratoriów badawczych i wzorcujących.

Lau, J., Chen, Q. (2006). Energy analysis for workshops with floor-supply displacement ventilation under the U.S. climates. Energy and Buildings, 38, 1212-1219. doi: 10.1016/j.enbuild.2006.02.006

LBNL (2007). EnergyPlus Engineering Reference. 06.11. 2007, p384, p381.

Mochida, A., Yoshino, H., Takeda, T., Kakegawa, T., Miyauchi, S. (2005). Methods for controlling airflow in and around a building under cross ventilation to improve indoor thermal comfort. Journal of Wind Engineering and Industrial Aerodynamics, 93, 437-449. doi: 10.1016/ j.jweia.2005.02.003

Nazaroff, W. W. (2008). Inhalation intake fraction of pollutants from episodic indoor emissions. Building and Environment, 43 (3), 269-277. doi: 10.1016/j.buildenv.2006.03.021

PN-B-03430:1983. Wentylacja w budynkach mieszkalnych zamieszkania zbiorowego i użyteczności publicznej - wymagania.

Santamouris, M. i Wouters, P. (2006). Building ventilation: The state of the art. London: Earthscan.

Tombazis A. N. (1999). Architecture and Bioclimatic Design - Less is Beautiful. W A. Krishan, N. Baker, S. Yannas i S.V. Szkolay (red.), Climate Responsive Architecture: A Design Handbook For Energy Efficient Buildings (strony 3-12). New Delhi: Tata McGraw-Hill. 


\section{CHIMNEY POT - A WAY OF INTENSIFYING NATURAL VENTILATION IN RESIDENTIAL BUILDINGS}

\section{ABSTRACT}

In Poland, natural ventilation is the most popular method of ventilating rooms, including premises in residential buildings. This type of ventilation works under the influence of the forces of nature due to the pressure difference between the external air and the inside air, as a result of which natural ventilation is difficult to control and predict the correctness of its functioning. Natural ventilation works best in winter when there is a large temperature difference and on windy days, when the wind speed exceeds $3 \mathrm{~m} \cdot \mathrm{s}^{-1}$, while the worst in terms of efficiency of natural ventilation is the spring-autumn transition period. In order to improve the effectiveness of ventilation chimney pot is used, which is designed to improve the chimney effect. The efficiency of ventilation determines the demand for ventilation air in rooms. The efficiency of natural ventilation $(A C H)$ is determined based on the dependence in which it is necessary to estimate the amount of air leaving the ventilation system in relation to the volume of the ventilated room. The article presents the influence of the chimney pot on the efficiency of gravitational ventilation through the determined $A C H$ values. The work uses the results from field tests carried out in the existing building.

Key words: chimney pot, gravity ventilation, $\mathrm{ACH}$ 